\title{
PERUBAHAN SIFAT MEKANIS DAN STRUKTUR MIKRO BAJA JIS G4051 S15C AKIBAT HARDENING DENGAN VARIASI MEDIA PENDINGIN
}

\author{
Media Nofri ${ }^{1}$ \\ Program Studi Teknik Mesin, Institut Sains dan Teknologi Nasional, Jakarta Selatan, Indonesia ${ }^{12}$ \\ email $^{1}$ : medi.bagindo@gmail.com
}

\begin{abstract}
Testing is an experiment to know the change of mechanical properties and micro structure in JIS G 4051 S 15 C series steel which is previously was cooled with some variation of media such as immersion into water, oil and cooling in free air then the test include: chemical composition, hardness, Impact, Fractography and Metallography. From result of testing the chemical composition with main integer element got result: $0.15 \% \mathrm{C}$, $0.157 \%$ Si, $1.2 \% \mathrm{Mn}, 0.01 \% \mathrm{P}, 0.02 \%$ S. Hardness test results with Vickers method obtained $183 \mathrm{HV}$ for original test object (original), $182.66 \mathrm{HV}$ for water-cooled test specimens, $190.33 \mathrm{HV}$ cooled with oil and $196.33 \mathrm{HV}$ cooled with air. While in the impact test the toughness value is 0.5 Joule / $\mathrm{mm} 2$ for the original test object, 0.39 Joule / $\mathrm{mm} 2$ water-cooled test specimens, 0.56 Joule / $\mathrm{mm} 2$ oil-cooled specimen, and $0.61 \mathrm{Joule} / \mathrm{mm} 2$ cooled test object With free air. In Fractography testing can not be further analyzed the type of fracture, because the photo does not showed the form of cracks or fault plot. While the metallographic results for the original test object or non heat treatment structure is Ferrite and Pearlit, after Hardening the structured remains Ferrit and Pearlit, there is a change in the structure form into Martensit. The mechanical properties generated after the testing process on the JIS G 4051 S 15 C steel have increased the toughness and decreased the hardness so that the steel can be summarize to be more resilient than the original.
\end{abstract}

\section{PENDAHULUAN}

Penggunaan baja JIS G 4051 S 15 C dengan kadar karbon rendah banyak digunakan untuk bagian-bagian konstruksi seperti: jembatan, pagar, rangka atap dan lain-lain.

Berdasarkan penggunaannya baja jenis ini terus dilakuakan pengembangan dengan tujuan untuk memiliki sifat mekanik yang lebih baik terutama kekerasan, kekuatan dan ketangguhan, hal ini dapat diperoleh yang salah satunya melalui proses pemanasan dengan pendinginan cepat, akan tetapi proses ini mengalami penurunan ketangguhan dari baja tersebut.

Permasalahan yang akan dihadapi adalah baja JIS G 4051 S 15 C banyak digunakan untuk keperluan kontruksi dan industri. Dan didalam praktek dilapangan sering terjadi perubahanperubahan kekuatan sehingga diperlukan inovasiinovasi dalam rangka meningkatkan kekuatan material, misalnya dengan melakukan proses heat treatment, penguatan karena larutan padat, penguatan oleh partikel halus, penguatan akibat batas butir dan atau penguatan karena struktur pengerjaan dingin

Tujuan dilakukan pengujian ini adalah:

Melihat pengaruh Hardening pada proses pengerasan baja JIS G 4051 S 15 C terhadap struktur mikro, kekerasan, impak dan fraktografi dengan variasi media pendingin, sehingga didapat sifat mekanis bahan setelah mengalami Hardening.

\section{TINJAUAN PUSTAKA \\ Baja Karbon}

Baja karbon merupakan paduan besi dan karbon sebagai paduan utama dengan kandungan karbon kurang dari 1,7\% dan sangat sedikit mengandung unsur-unsur lainnya. Baja karbon terdiri dari 3 jenis yaitu baja karbon rendah ( $\mathrm{C}<0,2 \%)$, baja karbon medium $(0,2 \%<\mathrm{C}<0,5 \%)$ dan baja karbon tinggi $(0,5 \%<\mathrm{C}<1,7 \%)$. Dan untuk penelitian ini baja JIS G 4051 S 15 C adalah baja karbon rendah 


\section{Proses Perlakuan Panas (Heat Treatment) Definisi Heat Treatment}

Heat Treatment adalah proses pemanasan dan pendinginan yang terkontrol dengan maksud mengubah sifat dari logam yang dimaksud. Heat Treatment secara umum:

1. Pemanasan sampai suhu dan kecepatan tertentu.

2. Mempertahankan suhu untuk waktu tertentu sehingga temperaturnya merata.

3. Pendinginan dengan media pendingin (air, oli dan udara).

Syarat-syarat Heat Treatment:

1. Suhu pemanasan harus naik secara teratur dan merata.

2. Alat ukur hendaknya seteliti mungkin.

\section{Klasifikasi Proses Heat Treatment}

Secara umum Heat Treatment dapat diklasifikasikan sebagai berikut :

1. Hardening

2. Tempering

3. Anealing

4. Normalizing

\section{Hardening}

Tujuan :

Merubah struktur baja sedemikian rupa sehingga diperoleh struktur yang keras.

\section{Proses:}

Baja dipanaskan sampai temperatur tertentu antara $770-830^{\circ} \mathrm{C}$ (tergantung dari kadar karbon) kemudian ditahan pada temperatur tersebut beberapa saat yang selanjutnya didinginkan secara cepat dengan mencelupkan dalam air, oli ataupun media pendingin yang lain

Hasil: Kekerasan tinggi.

\section{Pengujian Impak}

Ketangguhan adalah kemampuan suatu bahan untuk menyerap energi tetapi tidak sampai hancur/rusak, atau kemampuan suatu bahan untuk menerima beban yang mendadak/tiba-tiba.

\section{Batang uji Charpy}

Mempunyai luas penampang lintang bujursangkar $(10 \times 10 \mathrm{~mm})$ dan mengandung takik $\mathrm{V}=45^{\circ}$ degan jari-jari dasar $0,25 \mathrm{~mm}$ dan kedalaman $2 \mathrm{~mm}$

\section{Batang uji Izod}

Mempunyai penampang lintang bujur sangkar atau lingkaran dan bertakik $\mathrm{V}$ didekat ujung yang dijepit (saat ini batang uji Izod sudah jarang digunakan) Kerja (usaha) yang diperlukan untuk mematahkan benda uji yang telah distandarisasikan merupakan ukuran keuletan :

Untuk perhitungan Impak Test dapat dirumuskan:

$\mathrm{W}=\mathrm{F}_{\mathrm{g}} \mathrm{X}$ (h1-h2)

Dimana :

$$
\begin{aligned}
& \mathrm{W}=\text { Kerja pukulan }(\mathrm{Nm}=\mathrm{J}) \\
& \mathrm{Fg}=\text { Massa palu }(\mathrm{Kg}) \\
& \mathrm{h} 1=\text { Tinggi awal kedudukan palu }(\mathrm{m}) \\
& \mathrm{h} 2=\text { Tinggi ayunan akhir setelah patah }
\end{aligned}
$$

(m)

Kerja patah ini dibagi dengan luas batang dibawah tekanan maka kita dapatkan kerja patah persatuan luas atau nilai pukulan takik.

$$
\mathrm{K}=\frac{\mathrm{W}}{\mathrm{A}_{0}}
$$

\section{Dimana :}

$\mathrm{K}=$ Nilai pukulan takik $\left(\mathrm{J} / \mathrm{mm}^{2}\right)$.

$\mathrm{A}_{0}=$ Penampang batang semula dibawah takikan $\left(\mathrm{mm}^{2}\right)$.

\section{Sifat Mekanik}
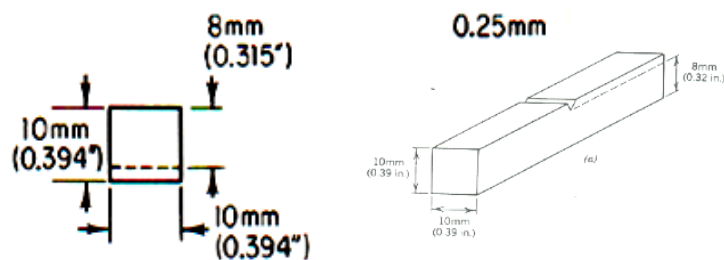

Gambar 1 : Bentuk uji Impak untuk tipe charpy
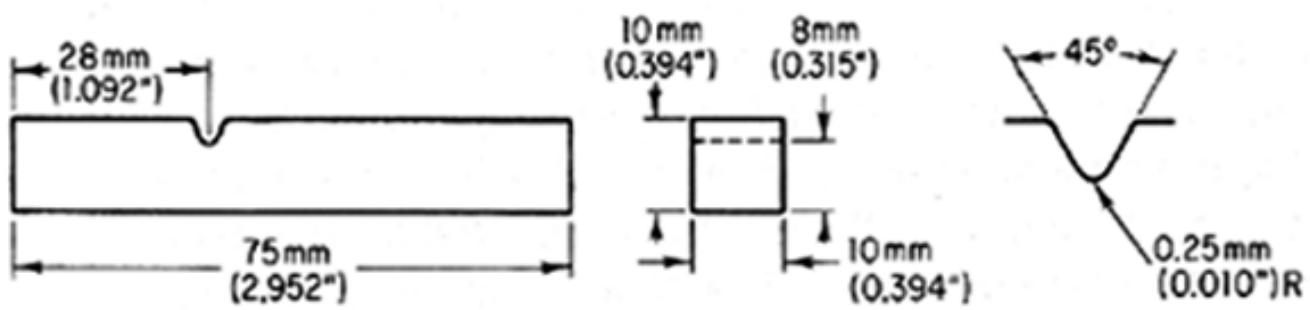

Gambar 2 : Bentuk uji Impak untuk tipe izod 


\section{Kekerasan}

Pada umumnya kekerasan menyatakan ketahanan material terhadap deformasi plastis atau permanen. Umumnya ada 3 cara untuk menentukan kekerasan material yaitu : Cara Goresan, Cara Dinamik dan Cara Penekanan

Pengukuran secara Vickers dilakukan dengan penekan oleh intan berbentuk piramida bersudut puncak $136^{\circ}$. Sudut ini dipilih, Karena nilai tersebut mendekati sebagian besar nilai perbandingan yang diinginkan antara diameter bola penumpuk pada uji kekerasan Vickers. DPH dapat ditentukan dari persamaan berikut:

$$
H V=\frac{2 P \sin (\theta / 2)}{D^{2}}=\frac{1.854 P}{D^{2}}
$$

Dimana :

$$
\begin{gathered}
\mathrm{P}=\text { Beban yang ditetapkan, } \mathrm{kg} \\
\mathrm{D}=\text { Panjang diagonal rata-rata, } \mathrm{m}
\end{gathered}
$$

\section{Fraktografi}

Perpatahan adalah pemisahan atau pemecahan suatu benda padat menjadi dua bagian atau lebih diakibatkan adanya tegangan/beban. Perpatahan terjadi dalam berbagai cara tergantung pada keadaan tegangan, laju pemberian tegangan dan suhu. Proses perpatahan terdiri atas dua tahap yaitu timbulnya retak dan tahap penjalaran retak. Patahan karena beban statis ini umumnya terjadi pada laju pembebanan yang tinggi atau jika material mendapat beban kejut. Ada dua jenis patahan yaitu Transgranular fracture (patahan transkristalin) dan Intergranular fracture

Transgranular fracture (patahan transkristalin) patahan merambat melalui butir. Selain itu ciri permukaan yang tampak cendrung planar atau konkoidal dan hanya merupakan ciri proses patahan tanpa indikasi yang jelas mengenai struktur dasar butir

Intergranular fracture (patahan interkristal) paling mudah dikenali dari jejak patahan melalui melalui batas butir pada sample yang gagal atau yang diuji

Kedua jenis patahan tadi dapat dibagi lagi berdasarkan sifatnya yaitu :

1. Patah Liat (ductile fracture)

2. Patah Getas (brittle fracture)

Patah Liat (ductile fracture) ditandai oleh deformasi plastis yang cukup besar sebelum dan sesudah proses penjalaran, pada permukaan patahan biasanya nampak adanya deformasi yang cukup besar.

Patah liat ini biasanya diawali dengan adanya geseran disepanjang bidang yang menerima tegangan geser maksimum. Ciri utamanya adalah permukaan patah gelap, berserat dan secara makro terlihat permukaan patahan berbentuk geseran. Untuk logam yang bersifat ulet, bila menerima pembebanan akan mengalami perubahan bentuk (deformasi) tidak hanya bagian luar logam akan tetapi juga pada rongga-rongga udara atau cacat-cacat lain yang ada dalam logam tersebut

Jadi selama deformasi plastis dan elastis struktur mikro akan berkonstruksi diantara rongga-rongga didalam suatu daerah yang nantinya merupakan basis daripada permukaan patahan. Bila logam tersebut patah maka ronggarongga atau cacat-cacat didalam logam akan meninggalkan jejak yang disebut Dimple

Patah Getas (brittle fracture), ditandai oleh adanya kecepatan penjalaran retak yang tinggi tanpa terjadi deformasi kasar dan sedikit sekali terjadi deformasi mikro. Patah ini terjadi apabila material/komponen logam pada saat patah tidak mengalami perubahan bentuk atau pengecilan penampang

Faktor-faktor yang berperan dalam proses patah rapuh adalah :

a. Besar, arah dan kecepatan pembebanan

b. Keadaan material misalnya adanya inklusi, porositas, sifat rapuh

c. Adanya retakan-retakan yang tidak diketahui

d. Temperatur yang sangat rendah dibawah $0^{\circ} \mathrm{C}$

Ada dua macam patah getas/rapuh yang spesifik yaitu Patah Interkristalin, yang banyak terjadi apabila sepanjang perbatasan banyak endapan dan Patah Transkristalin yang terjadi bila garis patahan menyilang langsung permukaan kristalnya

\section{Metallografi}

Pengamatan ini dilakukan untuk mempelajari dan untuk mengetahui struktur mikro dari logam, yang meliputi bentuk besar butiran dan arah struktur. Struktur mikro tersebut sangat menentukan sifat mekanis logam yang diuji.

Metode pengujian ini memerlukan persiapan yang cukup teliti dan cermat, agar diperoleh hasil metallografi yang baik, oleh karena itu diperlukan beberapa tahap dalam persiapannya yaitu, Pemotongan benda uji, Mounting, Grinding, Polishing, Etsa dan Pengujian Struktur Mikro 


\section{Diagram Alir Proses Pengujian}

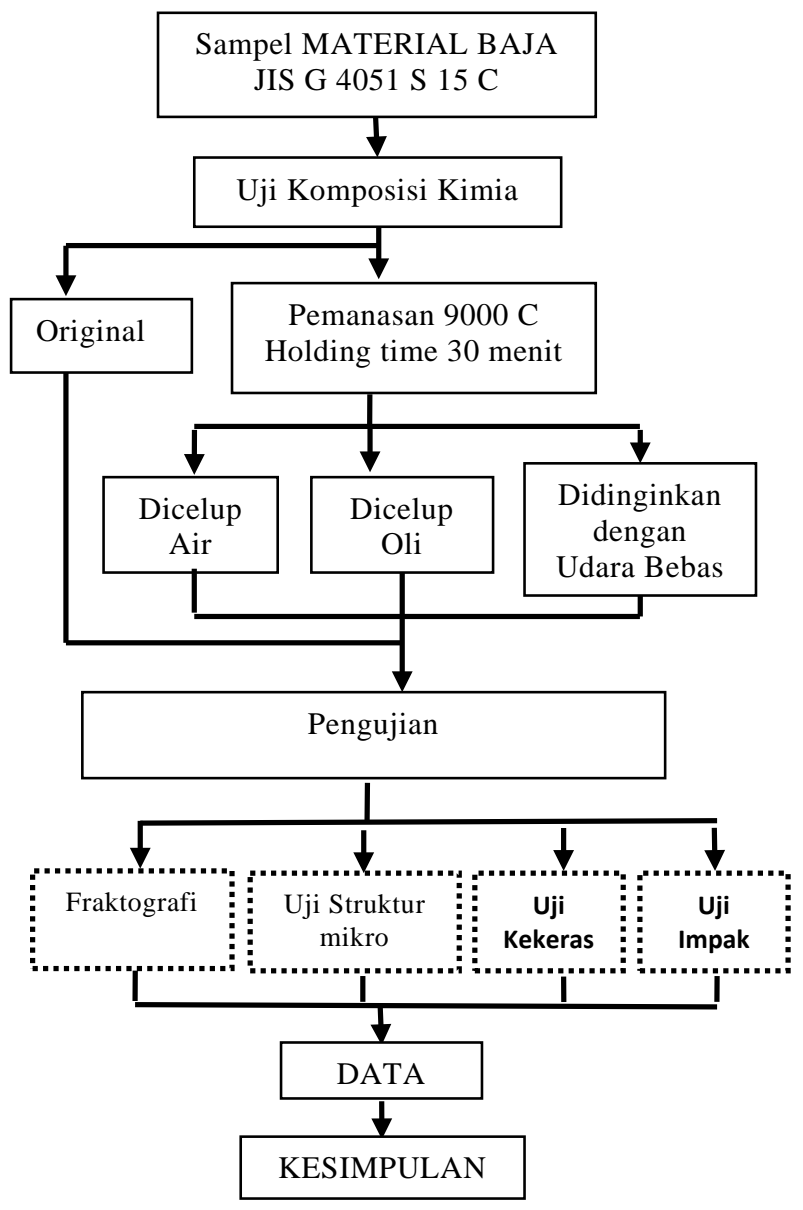

Gambar 3. Diagram alir proses pengujian.

\section{PEMBAHASAN}

Hasil Uji Komposisi Kimia

Setelah melakukan uji komposisi kimia pada baja JIS G 4051 S15 C maka di dapat data yang terlihat pada tabel 1 di bawah ini

Tabel 1: Hasil pengujian komposisi kimia

\begin{tabular}{|l|l|l|}
\hline No & Komposis Kimia & Kadar \% \\
\hline 1 & Carbon ( C ) & 0.15343 \\
\hline 2 & Silicon ( Si ) & 0.15795 \\
\hline 3 & Sulfur ( S ) & 0.0203 \\
\hline 4 & Phosphorus ( P ) & 0.0145 \\
\hline 5 & Manganese ( Mn ) & 1.28029 \\
\hline 6 & Nickel ( Ni ) & 0.01918 \\
\hline 7 & Chromium ( Cr ) & 0.02659 \\
\hline 8 & Molybdenum( Mo ) & 0.00009 \\
\hline 9 & Vanadium ( V ) & 0.00232 \\
\hline 10 & Copper ( Cu ) & 0.0255 \\
\hline 11 & Wolfram ( W ) & 0.00209 \\
\hline 12 & Tintanium ( Ti ) & 0.00166 \\
\hline 13 & Tin ( Sn ) & 0.00171 \\
\hline 14 & Aluminum ( Al ) & 0.02806 \\
\hline
\end{tabular}

\begin{tabular}{|l|l|l|}
15 & Lead ( Pb ) & -0.00145 \\
\hline 16 & Niobium ( Nb ) & 0.03537 \\
\hline 17 & Zirconium ( Zr ) & 0.00005 \\
\hline 18 & Zinc ( Zn ) & 0.00035 \\
\hline 19 & Iron (Fe) & 98.2322 \\
\hline
\end{tabular}

Hasil Uji Impak

Pada pengujian Impak di dapat hasil yang bervariasi dari masing-masing benda uji, baik original maupun setelah di lakukan pemanasan dengan media pendinginan yang berbeda terlihat pada tabel 2 di bawah ini :

Tabel 2: Hasil pengujian Impak

Hasil Uji Kekerasaan

Pada hasil pengujian dengan meggunakan metode kekerasan Vickers dimana Indentor pengujian kekerasan Vickers yang digunakan adalah dengan beban penekanannya sebesar $5 \mathrm{Kg}$ dengan 3 titik tekanan yang hasil terlihat pada tabel 3 dibawah ini :

Tabel 3: Hasil pengujian kekerasan Vickers

\begin{tabular}{|c|c|c|c|c|}
\hline Benda Uji & $\begin{array}{l}\text { Tempe } \\
\text { ratur }\end{array}$ & $\begin{array}{l}\text { Holding } \\
\text { Time }\end{array}$ & $\mathrm{HV}$ & $\begin{array}{l}\text { HV } \\
\text { Rata- } \\
\text { rata }\end{array}$ \\
\hline Original & $28^{\circ} \mathrm{C}$ & & $\begin{array}{l}185 \\
186 \\
178\end{array}$ & $\begin{array}{l}183 \\
\mathrm{HV}\end{array}$ \\
\hline $\begin{array}{l}\text { Dicelup } \\
\text { dengan Air }\end{array}$ & $900^{\circ} \mathrm{C}$ & $\begin{array}{l}30 \\
\text { menit }\end{array}$ & $\begin{array}{l}302 \\
317 \\
321 \\
\end{array}$ & $\begin{array}{l}313 \\
\text { HV }\end{array}$ \\
\hline $\begin{array}{l}\text { Dicelup } \\
\text { dengan Oli }\end{array}$ & $900^{\circ} \mathrm{C}$ & $\begin{array}{l}30 \\
\text { menit }\end{array}$ & $\begin{array}{l}214 \\
227 \\
216\end{array}$ & $\begin{array}{l}219 \\
\text { HV }\end{array}$ \\
\hline $\begin{array}{l}\text { Didinginkan } \\
\text { di udara } \\
\text { bebas }\end{array}$ & $900^{\circ} \mathrm{C}$ & $\begin{array}{l}30 \\
\text { menit }\end{array}$ & $\begin{array}{l}154 \\
158 \\
158\end{array}$ & $\begin{array}{l}156 \\
\text { HV }\end{array}$ \\
\hline
\end{tabular}

\begin{tabular}{|l|l|l|l|}
\hline Sampel & $\begin{array}{l}\text { Luas } \\
\text { Penampang } \\
\text { (mm2) }\end{array}$ & $\begin{array}{l}\text { Energy } \\
\text { Impak } \\
\text { (Joule) }\end{array}$ & $\begin{array}{l}\text { Harga } \\
\text { Impak } \\
\text { (Joule/m } \\
\text { m2) }\end{array}$ \\
\hline Original & 64 & 32 & 0.5 \\
\hline $\begin{array}{l}\text { Dicelup } \\
\text { dengan Air }\end{array}$ & 64 & 12 & 0.187 \\
\hline $\begin{array}{l}\text { Dicelup } \\
\text { Dengan Oli }\end{array}$ & 64 & 30 & 0.468 \\
\hline $\begin{array}{l}\text { Didinginkan } \\
\text { di udara } \\
\text { bebas }\end{array}$ & 64 & 39 & 0.609 \\
\hline
\end{tabular}


Hasil Foto Fraktografi

Pada pengujian fraktografi tidak terlihat maupun mendapatkan hasil yang diinginkan dikarenakan kesalahan pada pengujian terlihat pada gambar 4 .

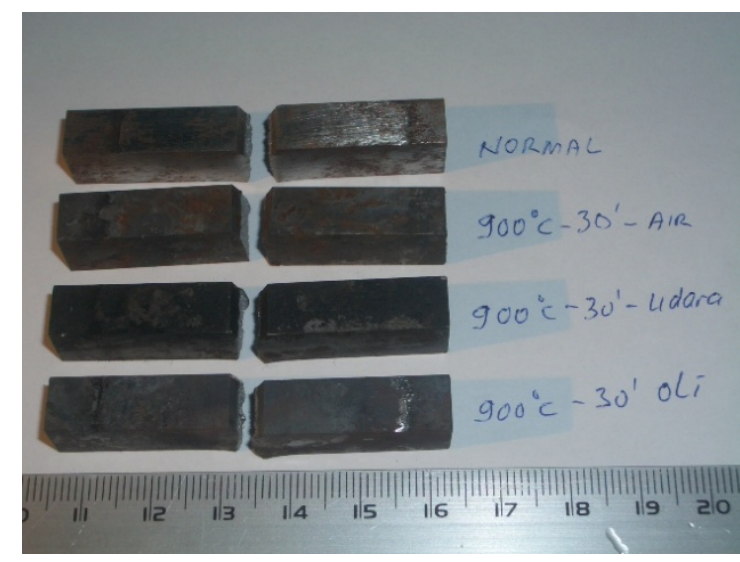

Gambar 4: Foto sampel fraktografi

\section{Hasil Foto Metallografi}

Hasil metallografi pada setiap benda uji antara benda uji yang di hardening, terlihat pada gambar 5 sampai gambar 8.

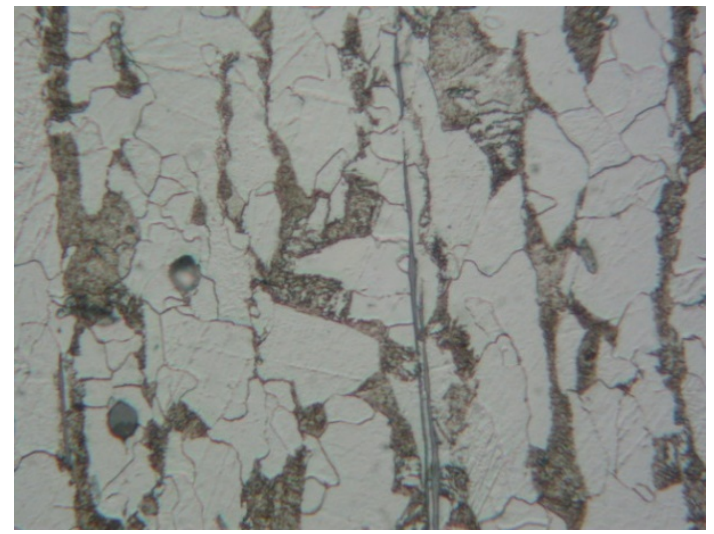

Gambar 5: Foto sampel metallografi Original dengan perbesaran $1000 \mathrm{X}$

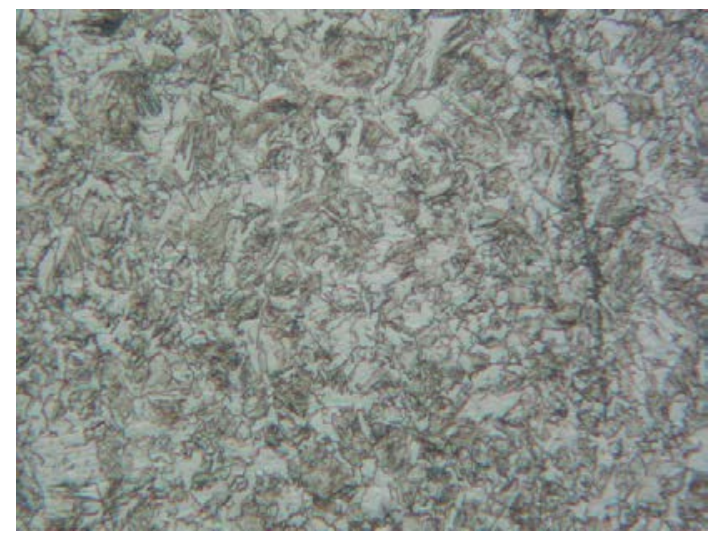

Gambar 6: Foto sampel metallografi di celup dalam air dengan perbesaran $1000 \mathrm{X}$

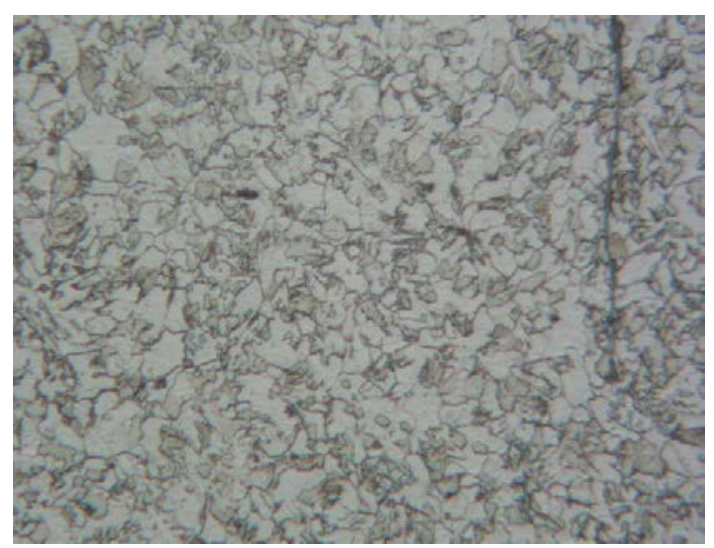

Gambar 7: Foto sampel metallografi di celup dalam oli dengan perbesaran $1000 \mathrm{X}$

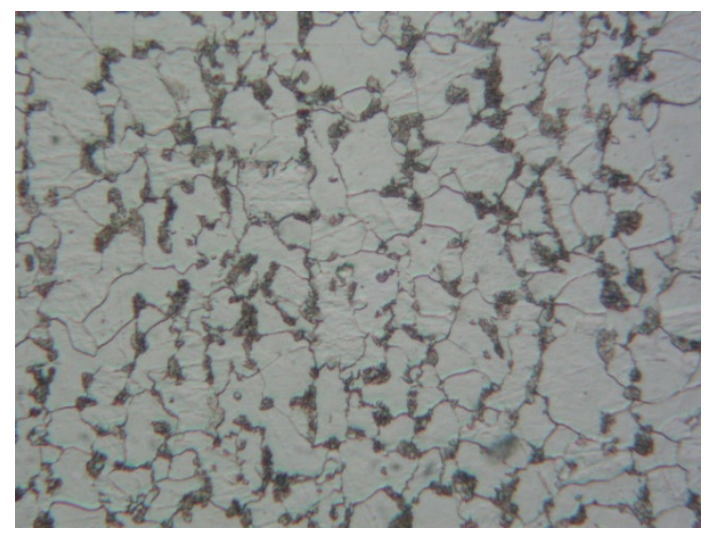

Gambar 8: Foto sampel metallografi didinginkan di Udara Bebas dengan perbesaran 1000X

\section{Analisis Komposisi Kimia}

Baja JIS G 4051 S 15 C, termasuk baja kadar karbon rendah, dengan kadar karbon (C) 0.15343\%, Silikon (Si) 0,15795\%, Sulfur (S) 0,0203\%, Phosphorus (P) 0,0145\%, Manganese (Mn) 1,28029\%. Unsur paduan utamanya adalah Karbon dan Mangan, sehingga bisa dikatakan bahwa Baja JIS G4051 S15C bukanlah baja paduan, karena terlihat dari hasil uji komposisi kimia walaupun ada beberapa komposisi diluar unsur utama baja, seperti $\mathrm{Cr}, \mathrm{V}$, Mo nilainya tidak tinggi

Dengan kadar Karbon 0.15343\% dalam besi dapat menaikan kekuatan, kekerasan baja tetapi keuletannya akan menurun dibandingkan dengan baja Ferrit yang berkadar karbon $\leq 0,02 \%$. Sedangkan kadar Mangan sebesar 1.28029\% berfungsi sabagai de-oksidasi dari baja dan Mangan juga mengikat Sulfur (S) dengan membentuk senyawa MnS yang titik cairnya lebih tinggi dari titik cair baja dan juga untuk mencegah hot shortness (kegetasan pada suhu tinggi) terutama pada proses pengerolan panas, disamping itu Mangan menguatkan fasa Ferrit.

Terlihat kadar Si sebesar 0,15795\% lebih kecil dalam batas normal yaitu antara $0,25 \%$ sampai dengan $0,8 \%$, sehingga akan dapat menurunkan 
kekuatan baja, karena dengan kadar Si diatas 0,15795\% dapat meningkatkan kekauatan baja tanpa mengakibatkan penurunan terhadap sifat keuletannya. Sedangakn Phospor (P) sebesar 0,0145\%, (maximum 0,04\%) nilai yang normal oleh karena dengan jumlah tersebut akan meningkatkan kekuatan dan kekerasan, tetapi keuletannya cendrung turun dan mudah mengalami retak atau getas pada suhu rendah, sehingga peka terhadap beban benturan. Adapun Sulfur (S) sebesar 0,0203\% (maximum 0,05\%) masih dalam batas normal, sehingga Sulfur ini akan menurunkan sifat keuletan dan ketangguhan (terhadap beban benturan). Sulfur yang berlebihan akan bereaksi dengan $\mathrm{Fe}$ membentuk FeS sehingga terjadi diskontiunitas struktur yang disebut Hot-Shortness (kegetasan pada suhu tinggi) ketika mengalami proses Hot-Rolling atau ketika mengalami proses pengelasan.

\section{Analisis Uji Impak Sebelum dan Sesudah Heat Treatment}

Dalam pengujian Impak ini terdapat beberapa sampel, yaitu sampel material non heat treatment, material setelah di Hardening dengan media pendingin air, oli dan di dinginkan pada udara bebas.

Pengujian Impak adalah untuk mengetahui nilai ketangguhan sebagai fungsi dari temperatur

Dari hasil pengujian dapat dibuat gambar atau grafik dimana dari hasil pendinginan dengan air nilai impaknya kecil yang berarti energi yang dibutuhkan untuk mematahkan sample relatif kecil, hal ini menandakan material tersebut mempunyai nilai kegetasan yang cukup tinggi

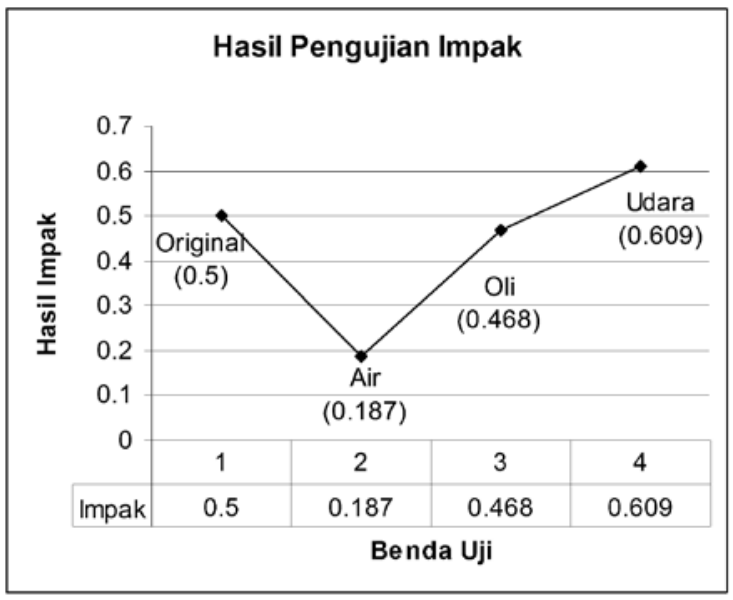

Gambar 7: Hasil pengujian Impak.

Pada material non heat treatment (tabel 2) nilai harga Impaknya adalah 0,5 (joule $/ \mathrm{mm}^{2}$ ), setelah dilakukan hardening dengan media pendingin air didapat hasil sebesar 0,187 (Joule/ $\mathrm{mm}^{2}$ ), sedangkan harga impak pada pencelupan dengan oli didapat hasil sebesar 0,468 (Joule/ $\left.\mathrm{mm}^{2}\right)$ dan setelah dilakukan percobaan dengan media pendingin udara bebas dihasilkan nilai impak 0,609 (Joule/mm²). Dan mempunyai jenis patahan ulet/liat

Sedangkan pada pengujian material yang di Hardening dengan metoda pencelupkan air dan oli nilai harga Impaknya menurun, ini dikarenakan pada proses Hardening hanya untuk mengeraskan material tetapi tidak untuk keuletanya sehingga harga Impaknya semakin menurun.

\section{Analisis Uji Fraktografi}

Pada pengujian Fraktografi tidak terlihat maupun mendapatkan hasil yang diinginkan dikarenakan kesalahan pada pengujian. Kemungkinan hal ini dapat terjadi dikarenakan adanya kesalahan pada alat atau instrument uji Fraktografi atau kesalahan operator dalam menjalankan perlatan

\section{Analisis Kekerasan Sebelum dan Sesudah Heat Treatment}

Kekerasan adalah suatu ukuran ketahanan material terhadap deformasi plastis. Kemampuan benda uji menahan tekanan indentor yang diartikan sebagai kekerasan dari material.

Hasil dari pengujian kekerasan tersebut dapat dibuat grafik seperti terlihat pada gambar 8 .

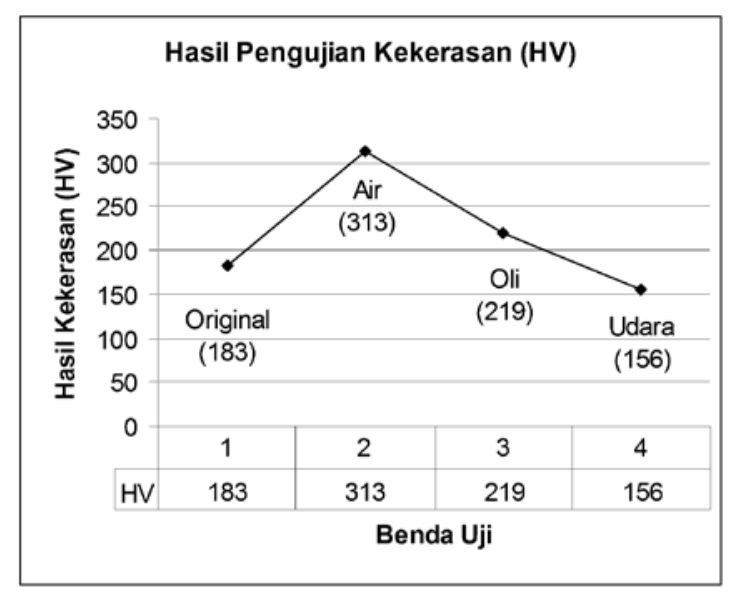

Gambar 8: Hasil pengujian Kekerasan (HV).

Pada Pengujian material non heat treatment (Original) nilai kekerasan Vickersnya adalah 183 HV dan kemudian dilakukan proses hardening dengan metoda pencelupan dengan air yang menyebabkan kekerasannya naik yaitu $313 \mathrm{HV}$, sedangkan dengan oli yaitu 219 HV terjadi penurunan kekerasan yang cukup sangat kuat dibandingkan dengan air, setelah dilakukan percobaan hardening dengan didinginkan udara bebas hasil kekerasannya terjadi penurunan dibanding dengan pencelupan oli yaitu sebesar 156 HV. 


\section{Analisis Struktur Mikro Sebelum dan Sesudah Heat Treatment}

Hasil dari foto metallografi dengan proses non heat treatment dan heat treatment terbagi menjadi 4 bagian yaitu dengan metoda dicelup dalam air, oli, dan didinginkan dengan udara bebas. Foto metallografi pada material non heat treatment dengan sisi bagian samping dan posisi tegak lurus akan terlihat struktur Ferrit dan Pearlit, dimana struktur Ferrit adalah merupakan kristal besi murni (ferrum $=\mathrm{Fe}$ ), yang terbentuk pada proses pendinginan yang lambat dari austenite baja hipoeutektoid pada saat mencapai A3 dan ferrit bersifat sangat lunak, ulet dan memiliki kekerasan sekitar $70-100$ BHN serta memiliki konduktivitas yang tinggi. Ferrit merupakan bagian baja yang paling lunak dan Ferrit murni tidak akan cocok andai kata digunakan sebagai bahan untuk benda kerja yang mehahan beban karena kekuatannya kecil.

Pearlite adalah campuran eutectoid antara ferrite dan cementite yang dibnetuk pada temperatur $723{ }^{\circ} \mathrm{C}$ dengan kandungan karbon 0,83\% dan memiliki kekerasan sekitar 10-30 HRC yang tampak seperti pelat-pelat yang tersusun bergantaian

Pada foto metallografi material yang dilakukan proses Hardening dengan temperatur $900^{\circ} \mathrm{C}$, holding time 30 menit dan media pencelupan dengan air akan terlihat adanya struktur Ferrit dan Pearlit menuju martensit yang berbentuk seperti jarum.

Bila hal ini dikaitkan dengan hasil kekerasan terlihat nilai kekerasannya tinggi, hal ini karena struktur Ferrit berubah menjadi martensit, sehingga terjadi kenaikan kekerasan yang cukup tinggi

Sedangkan pada pencelupan oli dan dengan didinginkan udara bebas akan terlihat adanya struktur Ferrit dan Pearlit.

Terlihat pada gambar 8, akibat pencelupan dengan oli dan pendinginan dengan udara biasa (normal) terjadi penurunan kekerasan, hal ini akibat tidak terjadi Martensit, dimana struktur Ferrit tidak berubah menjadi Martensit

\section{Hubungan antara Uji Impak dengan Uji Kekerasan}

Hasil hasil uji impak dengan uji kekerasan yang kemudian dibuatkan suatu grafik yang menyatakan hubungan antara impak dengan kekerasan, maka didapat diagram seperti terlihat pada gambar 9 .

Dari gambar terlihat nilai kekerasan akibat hardening cukup tinggi yang juga diiringi dengan nilai impak yang juga tinggi. Hal ini menandakan nilai kegetasan tinggi, akibat adanya Martensit.

Martensit terjadi pada temperatur dibawah temperatur eutektoid karena struktur Austenite (kps) yang tidak stabil sehingga berubah menjadi struktur kpr secara serentak. Pada reaksi ini terjadi difusi, akan tetapi karena adanya pergeseran maka semua atom bergeser secara serentak. Perubahan ini sangat cepat sehingga semua karbon yang tertinggal tetap dalam larutan padat dan sturktur kpr yang terjadi berubah menjadi tetragonal (tpr) yang berbeda dengan Ferrit. Karena Martensit mempunyai struktur bukan kubik maka karbon terperangkap dalam kisi dan slip sulit terjadi sehingga Martensit menjadi keras, kuat tetapi getas.

Hasil dari empat proses heat treatment pendinginan dengan air mempunyai nilai tertinggi, yang disusul dengan oli dan terakihr dengan tanpa heat treatment (original) dan pendinginan udara

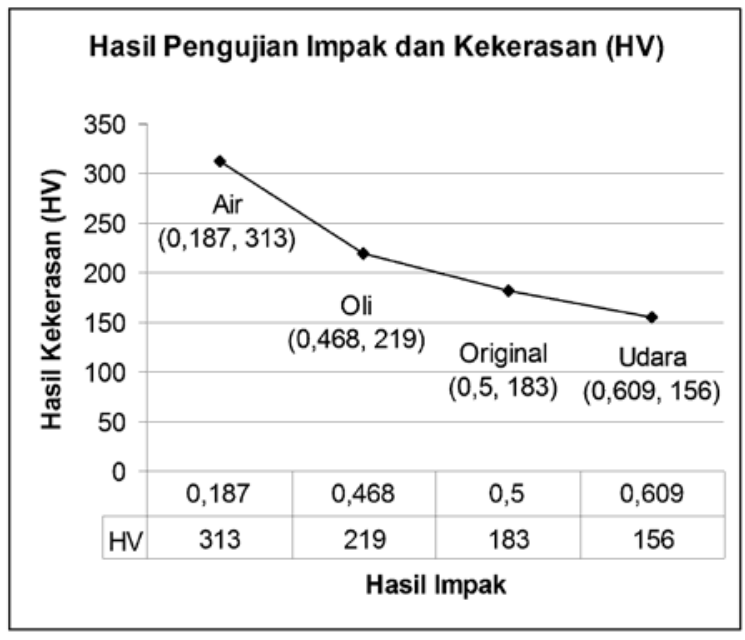

Gambar 9: Hasil pengujian Impak dan Kekerasan (HV)

Terlihat pada (Gambar 9) bahwa semakin keras baja tersebut, namun energi yang dibutuhkan untuk mematahkan material sangat kecil yang berarti baja tersebut getas.

Nilai tertinggi diperoleh dari proses Hardening yang disusul dengan pendingin dengan oli dan kemudian dengan proses tanpa heat treatment dan yang terakhir dengan pendinginan dengan udara,

Nilai kegetasan yang cukup tinggi terjadi pada proses Hardening dan secara runtut nilai kegetasan menurun pada proses pencelupan dengan oli sampai dengan pendinginan udara

\section{SIMPULAN}

1. Pengujian komposisi kimia baja JIS G $4051 \mathrm{~S}$ 15 C didapat dengan kadar karbon (C) 0.15343\%, Silikon (Si) 0,15795\%, Sulfur (S) 0,0203\%, Phosphorus (P) 0,0145\%, Manganese (Mn) 1,28029\%. Dimana kadar Silikon (Si) sedikit lebih kecil dari batas normal yang seharusnya $0,25 \%$ sampai dengan $08 \%$.

2. Pengujian Impak untuk material non heat treatment (Original) harga Impaknya adalah 0,5 (Joule/ $\mathrm{mm}^{2}$ ) dan patahannya adalah ulet. Sedangkan untuk material yang di Hardenig 
melalui metoda pencelupan dalam air harga impaknya adalah 0,187 (Joule/mm²), dan metoda dicelupkan didalam oli harga impaknya adalah 0,468 (Joule $/ \mathrm{mm}^{2}$ ), sedangkan metoda yang didinginkan dengan udara bebas harga impaknya adalah 0,609 (joule/ $/ \mathrm{mm}^{2}$ ).

3. Hasil dari pengujian kekerasan dengan metode Vikers untuk material non heat treatment (Original) nilai kekerasan Vickersnya adalah 183 HV dan kemudian dilakukan proses Hardening dengan metoda pencelupan dengan air yang menyebabkan kekerasannya naik yaitu $313 \mathrm{HV}$, sedangkan dengan oli yaitu $219 \mathrm{HV}$ terjadi penurunan kekerasan yang cukup sangat kuat dibandingkan dengan air, setelah dilakukan percobaan Hardening dengan didinginkan udara bebas hasil kekerasannya terjadi penurunan dibanding dengan pencelupan oli yaitu sebesar $156 \mathrm{HV}$.

4. Pada struktur metallografi untuk material non heat treatment strukturnya adalah Ferrit dan Pearlit. Dan pada foto metallografi material yang dilakukan proses Hardening dengan temperatur $900^{\circ} \mathrm{C}$, holding time 30 menit dan media pencelupan dengan air akan terlihat adanya struktur Ferrit dan Pearlit menuju Martensit yang berbentuk seperti jarum.

5. Sedangkan pada pencelupan oli dan dengan didinginkan udara bebas akan terlihat adanya struktur Ferrit dan Pearlit.

6. Pada pengujian Fraktografi tidak terlihat hasil yang diinginkan dikarenakan kesalahan pada pengujian.

Terlihat bahwa terjadi variasi perubahan sifat mekanik Baja JIS G 4051 S 15 C bila dilakukan proses Hardening, demikian juga dengan metoda dicelup atau didinginkan dengan air, kemudian oli dan juga bila didinginkan dengan udara bebas.

\section{DAFTAR PUSTAKA}

Avner Sidney H, Prof. 1974, Introduction to Physical Metallurgy. $2^{\text {nd }}$ edition, McGraw Hill International Book Company, New York, U.S.A.

Dieter, George E. “Metalurgi Mekanik”. Terjamah Sriati Djaprie, Edisi ketiga, Jilid 1 dan 2, Penerbit Erlagga, 1988.

Karl-Eric Thelning, 1981, Steel and its Heat Treatment, $3^{\text {and }}$ edition, Bofors Handbook

Stanley T Rolfe, Jhon M Barsom, 1977, Fracture and Fatigue Control in Structures, $4^{\text {and }}$ edition, Prentice-Hall, Inc, Englewood Cliffs, New Jersey

James F Shackelford, 1996, Introduction to Materials Science for Engineers, $4^{\text {and }}$ edition, Prentice-Hall International, Inc
James A Jacobs, Thomas F Kilduff, 1997, Engineering Materials Technology, $3^{\text {and }}$ edition, Prentice-Hall International, Inc

MS Tata Surdia and Saito Shinroku, Ir, Dr, Prof. Pengetahuan Bahan Teknik. Cetakan ke-5, PT Pradnya Paramita. Jakarta.

Smith William F, Prof. 1993, Principles of Materials Science and Engineering. $3^{\text {th }}$ edition, McGraw Hill International Book Company, New York, U.S.A. 